\title{
The role of black seed and/ or bees honey in modulating the heart disorder induced by food additives in male rats.
}

\author{
Wafaa M. El-Kholy; Hanaa A. Hassan and Samar E. Nour \\ Zoology Department, Faculty of Science, Mansoura University
}

\begin{abstract}
Background: The present study aimed to throw the light on the potential hazards of some food additives whether preservatives such as sodium nitrite or colors as sunset yellow on the heart disorders through their own effect or the interaction between them. The study also, investigated the possible protective role of black seed and/ or bees honey against such risks.

Results: Herein, the mentioned food additives caused significant elevations in serum and cardiac total lipids (TL), total cholesterol (TC), triglycerides (TG) and phospholipids (PL) levels as well as serum LDL-c, VLDL-c levels and LDL-c/HDL-c ratio. Meanwhile, significant decrements were shown in serum HDL-c level and HDL-c/TC ratio. Additionally, creatine kinase (CK) and aspartate transferase (AST) enzymes activity were increased significantly in serum and cardiac tissue.

Moreover, oxidative stress markers; lipid peroxidation product (MDA) and protein carbonyl group (PC) were increased significantly in the cardiac tissue. Regarding, antioxidants; glutathione (GSH) content, glutathione -S -transferase (GST) and catalase (CAT) enzymes activity were decreased significantly in the cardiac tissue.

Conclusion: However, the use of black seed and/ or bees honey ameliorated the disturbances observed indicating remarkable protection against the toxic effects of these food additives on the heart and offers more safety. Overall, here with the most pronounced effect was achieved by the combined treatment. In addition, the treatment by bees honey was more effective than black seed.
\end{abstract}

Keywords: Food additives,sunset yellow,sodium nitrite,rats.

\section{Introduction}

Food additives are common in our life and play an important role in human being's life. They are substances that not normally consumed as a food by itself and not normally used as a typical ingredient of the food, whether or not it has a nutritive value (Ismail et al., 2003). The principle classes of food additives are preservatives, coloring agents, flavours, emulsifiers and stabilizers (Lindsay, 1985).

Among these food preservatives is sodium nitrite which is used in preservation of cured meat, fish and milk. Although small doses of nitrite $(0.25 \mathrm{mg} / \mathrm{kg} /$ day $)$ were recommended by Egyptian standard (1989) in preserved food yet, nitrite can be changed in stomach into nitrosamine (Furukawa, 2000). The toxicological effects of nitrite in different mammalian species are well documented including impairment of certain defense mechanisms like to the inflammatory response and tissue injury (Desaint-Blanquot et al., 1983), carcinogenesis (Choi, 1985) and endocrine disturbance (Jahries et al., 1986).

Alternatively, food colors are an important characteristic and selection criterion for food choice. Among these colors is sunset yellow which is used in the textile, printing, paper manufacturing, pharmaceutical and food industries (Chung et al., 1992). Many of synthetic food colorants have side effects such as urticaria, genotoxic, clastogenic and carcinogenic effects (Combes and Haveland-Smith, 1982) and behavioral disorders in children (Pollock and Warner, 1990), endocrinal disturbances (Jennings et al., 1990).

However, several natural antioxidants co-administrated with food additives in order to ameliorate the adverse effects of food additives (Merken and Beecher, 2000). 
Black seed is the most natural antioxidant, it could be considered as a potential source of natural phenolic compounds (Caponio et al., 1999), having positive effects in the prevention of heart disease and cancer (Tuck and Hayball, 2002). Moreover, Black seed contain fixed and volatile oils mainly thymoquinone (Enomoto et al., 2001), proteins (Babayan et al., 1978), and minerals (El-Zawahry, 1997). Likewise, it has many properties as immune stimulation (El-Kadi and Kandil, 1986), anticancer (Salomi et al., 1991) and anti-inflammatory (Houghton et al., 1995).

Alternatively, Bees honey is one of the oldest medicines known (Zumla and Lulat, 1989). Honey is a by-product of bees comprised of monosaccharides (glucose and fructose), vitamins A, B-complex, C, $\mathrm{D}, \mathrm{E}, \mathrm{K}$ and beta-carotene as well as minerals and enzymes. Interestingly, honeys contain a number of components known to act as preservatives; these include $\alpha$-tocopherol, ascorbic acid, flavonoids, and other phenolics and enzymes such as glucoseoxidase, catalase and peroxidase (Ferreres et al., 1993). Recently, honey was reported to have antioxidative and radical scavenging properties (Aljadi and Kamaruddin, 2004).

Therefore, the present study aimed to demonstrate the adverse effects of these widely used additives on some biochemical parameters representing as risk factors for developing heart disorders in rats. In addition, the possible protective role of both black seed and bees honey was investigated.

\section{Material and methods}

\section{Chemicals:}

Food additives $\left(\mathrm{NaNO}_{2}\right.$ and sunset yellow) were purchased from Sigma Chemical Company. However, black seed and bees honey were obtained from local herb market. Food additives were given concomitantly in the form of freshly prepared aqueous solution of $\mathrm{NaNO}_{2}$ in a dose equal $10 \mathrm{mg} \mathrm{NaNO} / \mathrm{kg} /$ day according to Helal and Abdel Rahman (2005) using the stomach tube, while sunset yellow was supplemented in diet at a dose equal $0.6 \%$ w/w according to Tanaka (1996).
Regarding black seed powder, it was given to the rats with diet in a dose equal $4 \%$ w/w according to Ghanem et al. (2000). Meanwhile, aqueous solution of bees honey was administrated to rats in a dose of $2.5 \mathrm{~g} / \mathrm{kg}$ b.w/day according toYamada et al. (1999) using the stomach tube. Both black seed and bees honey were freshly prepared daily and given each alone or in combination, simultaneously with the food additives (6 days/ weeks) for 4 weeks.

\section{Animal grouping and experimental design:}

Forty eight male albino rats weighing about $100-140 \mathrm{~g}$ were used in this study. Animals were housed in stainless steel cages, fed on rat chew and offered water. The animals were divided into eight groups 6 rats each as follows:

1- Control group: the animals received basal diet.

2- Black seed group: the animals received black seed powder.

3- Bees honey group: the animals received bees honey.

4- Black seed and bees honey group: the animals received black seed powder in addition to bees honey.

5- Sodium nitrite and sunset yellow group: the animals received sodium nitrite plus sunset yellow.

6- Sodium nitrite and sunset yellow + black seed group: The animals received sodium nitrite plus sunset yellow and black seed powder.

7- Sodium nitrite and sunset yellow + bees honey group: The animals received sodium nitrite plus sunset yellow and bees honey.

8- Sodium nitrite and sunset yellow + black seeds + bees honey group: The animals received sodium nitrite plus sunset yellow and black seed powder, in addition to bees honey.

\section{Sampling:}

At the end of the experi-mental period, overnight fasted animals were sacrificed and blood samples were collected into chilled non-heparinized tubes, and then were centrifuged at $860 \mathrm{G}$ for $20 \mathrm{~min}$ at $4^{\circ} \mathrm{C}$. The separated sera were frozen at $20^{\circ} \mathrm{C}$ for biochemical analysis. In addition, the heart was removed, cleaned and cut into pieces. Tissue samples from a known portion of the heart were accurately 


\section{Wafaa M. El-Kholy et al}

weighed and homogenized (PotterElvehjem) in a 10 - fold volume of ice-cold distilled water for later biochemical analysis.

\section{Assay:}

Total lipids were determined by the method of Frings et al (1972), however, total cholesterol, triglycerides and HDL-c were determined according to the methods of Young (1995) by using kit purchased from SPINREACT, S.A. Ctra, Santa Coloma, Espain. While, LDL-c and VLDLc were calculated according to the method of Friedewald et al. (1972). Phospholipids were determined chemically by the method of Baginiski et al. (1972). CK and AST enzynes activity were accomplished using kit purchased from Elitech: Division de SEPPIMS, France and RAM kit according to the method of Young (1997) and Reitman and Frankel (1957) respectively.

Heart MDA, protein carbonyl group, GSH levels, GST and CAT activities were estimated chemically according to the method of Ohkawa et al. (1982), Smith et al. (1991), Prins and Loose (1969), Habig et al. (1974) and Bock et al. (1980) respectively using spectrophotometer (Cecil 1020).

\section{Statistical analysis:}

The results obtained in the present work were evaluated by One Way ANOVA (analysis of variance) test and post comparison was carried out with Tukey test. The results were expressed as means \pm standard error (SE). The values of $\mathrm{p} \leq 0.05$ were considered statistically significant (Snedecor and Cochran, 1982).

\section{Results}

From Table 1, there were significant increments in serum total lipids, total cholesterol, triglycerides and phospholipids in rats received $\mathrm{NaNO}_{2}$ plus sunset yellow compared to control group. These increases turned back to normal ranges when rats received black seed and bees honey each alone or in combination in addition to $\mathrm{NaNO}_{2}$ plus sunset yellow.

The data in Table 2, exhibited significant declines in HDL-c level and
HDL-c/TC ratio, this is in contrast to significant elevation in LDL-c and VLDL-c levels as well as LDL-c/ HDL-c ratio in $\mathrm{NaNO}_{2}$ plus sunset yellow treated rats compared to control group. Conversely, these parameters showed significant improvement in rats fed on black seed and/ or bees honey beside $\mathrm{NaNO}_{2}$ plus sunset yellow treatment.

Table 3 indicated that there were significant increases in cardiac total lipids, total cholesterol, triglycerides and phospholipids in rats received $\mathrm{NaNO}_{2}$ plus sunset yellow compared to control group. While these disturbances reversed significantly toward the normal values when rats received $\mathrm{NaNO}_{2}$ plus sunset yellow and fed on black seed or bees honey in single or in combination.

Concerning the effect of the $\mathrm{NaNO}_{2}$ and sunset yellow on serum and heart enzymes activitiy (Table 4), the result revealed significant increases in $\mathrm{CK}$ and AST activity comparing to control group. However, the activity of these enzymes were ameliorated significantly as $\mathrm{NaNO}_{2}$ plus sunset yellow treated rats fed on black seed or bees honey each alone or in combination, but yet still above the normal values.

Furthermore, the results shown in Table 5, illustrated that administration of $\mathrm{NaNO}_{2}$ and sunset yellow significantly increased the heart MDA and protein carbonyl concentrations but significantly decreased the content of GSH and the activity of GST and CAT enzymes comparing to control group. On the other hand, the administration of black seed and/ or bees honey with $\mathrm{NaNO}_{2}$ plus sunset yellow caused marked improvement in these parameters. Regarding the rats received black seed and bees honey alone, the data showed a beneficial effect in all the estimated parameters especially when they are in combination if compared with control group.

Concerning ANOVA analysis of the investigated parameters, it was revealed that the general effect between groups was significant $(p<0.05)$ throughout the experiment. 
The role of black seed and/ or bees honey

Table 1: Serum lipid profiles in control and different treated rat groups.

\begin{tabular}{|c|c|c|c|c|c|c|c|c|c|c|c|}
\hline & & & \multicolumn{8}{|c|}{ Animal Groups } & \multirow{2}{*}{$\begin{array}{c}\text { ANOVA } \\
\mathrm{P}\end{array}$} \\
\hline & & & Con. & B.S. & B.H. & $\begin{array}{l}\text { B.S.+ } \\
\text { B.H. }\end{array}$ & $\begin{array}{l}\mathrm{NaNO}_{2} \\
+ \text { + S.S.Y. }\end{array}$ & $\begin{array}{c}\mathrm{NaNO}_{2} \\
+ \text { S.S.Y. } \\
+ \text { B.S. }\end{array}$ & $\begin{array}{c}\mathrm{NaNO}_{2} \\
+ \text { S.S.Y. } \\
+ \text { + B.H. }\end{array}$ & $\begin{array}{c}\mathrm{NaNO}_{2} \\
+ \text { S.S.Y. } \\
+ \text { B.S. } \\
\text { B.H. }\end{array}$ & \\
\hline \multirow{4}{*}{ 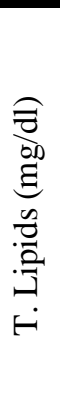 } & \multicolumn{2}{|c|}{ Mean } & 358.5 & 357.4 & 355.1 & 351.4 & 472.9 & 368 & 366.5 & 357.7 & \\
\hline & \multicolumn{2}{|c|}{$\pm \mathrm{SE}$} & 1.7 & 1.6 & 2.1 & 1.6 & $3.7^{\mathrm{a}}$ & $2.1^{\mathrm{b}}$ & $2.5^{\mathrm{b}}$ & $1.9^{\mathrm{b}}$ & \\
\hline & \multirow{2}{*}{$\begin{array}{c}\% \text { of } \\
\text { change }\end{array}$} & $*$ & & -0.30 & -0.94 & -1.9 & +31.9 & +2.6 & +2.2 & -0.22 & \\
\hline & & * & & & & & & -22.1 & -22.4 & -24.3 & \\
\hline \multirow{4}{*}{ 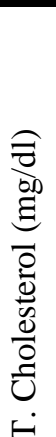 } & \multicolumn{2}{|c|}{ Mean } & 77.9 & 77.1 & 76.7 & 76.6 & 99.2 & 73 & 71.9 & 71.3 & $\mathrm{P}<0.05$ \\
\hline & \multicolumn{2}{|c|}{$\pm \mathrm{SE}$} & 1 & 1 & 1.1 & 1 & $1.1^{\mathrm{a}}$ & $1.1^{\mathrm{b}}$ & $1.4^{\mathrm{a} \& \mathrm{~b}}$ & $0.87^{\mathrm{a} \& \mathrm{~b}}$ & \\
\hline & \multirow{2}{*}{$\begin{array}{c}\% \text { of } \\
\text { change }\end{array}$} & $*$ & & -1 & -1.5 & -1.6 & +27.3 & -6.2 & -7.7 & -8.4 & \\
\hline & & * & & & & & & -26.3 & -27.5 & -28.1 & \\
\hline \multirow{4}{*}{ 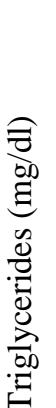 } & \multicolumn{2}{|c|}{ Mean } & 76.6 & 75.5 & 74.5 & 73.7 & 115.8 & 79.5 & 73.4 & 73.2 & \\
\hline & \multicolumn{2}{|c|}{$\pm \mathrm{SE}$} & 1.7 & 1.7 & 1.6 & 1.6 & $1.1^{\mathrm{a}}$ & $2.2^{\mathrm{b}}$ & $2.1^{\mathrm{b}}$ & $1.9^{\mathrm{b}}$ & \\
\hline & \multirow{2}{*}{$\begin{array}{c}\% \text { of } \\
\text { change }\end{array}$} & $*$ & & -1.4 & -2.7 & -3.7 & +51.1 & +3.7 & -4.1 & -4.4 & \\
\hline & & * & & & & & & -31.3 & -36.6 & -36.7 & \\
\hline \multirow{4}{*}{ 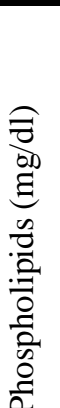 } & \multicolumn{2}{|c|}{ Mean } & 104.4 & 103.1 & 100.6 & 100.5 & 148.7 & 113.9 & 112.2 & 110.5 & $\mathrm{P}<0.05$ \\
\hline & \multicolumn{2}{|c|}{$\pm \mathrm{SE}$} & 1.2 & 1.3 & 1.8 & 0.90 & $1.3^{\mathrm{a}}$ & $1.2^{a \& b}$ & $1.2^{\mathrm{a} \& \mathrm{~b}}$ & $1.1^{\mathrm{a} \& \mathrm{~b}}$ & \\
\hline & \multirow{2}{*}{$\begin{array}{c}\% \text { of } \\
\text { change }\end{array}$} & $*$ & & -1.2 & -3.6 & -3.7 & +42.4 & +9.1 & +7.4 & +5.8 & \\
\hline & & * & & & & & & -23.4 & -24.5 & -25.6 & \\
\hline
\end{tabular}

Results are presented as means \pm SE and $\%$ of change ( $\mathrm{n}=6$ for each group).

$\%$ of change compared to control group (*) or compared to $\mathrm{NaNO}_{2}+$ S.S.Y group (**).

Significant change at $\mathrm{p} \leq 0.05$ compared to control group $\left({ }^{\mathrm{a}}\right)$ or compared to $\mathrm{NaNO}_{2}+$ S.S.Y. group $\left({ }^{b}\right)$.

B.S. : Black seeds. $\quad$ B.H. : Bees honey. S.S.Y. : Sunset yellow. 
Table 2: Serum HDL-C, LDL-C and VLDL-C levels as well as LDL-C/ HDL-C and HDL$\mathrm{C} /$ total cholesterol ratios in control and different treated rat groups.

\begin{tabular}{|c|c|c|c|c|c|c|c|c|c|c|c|}
\hline & & & \multicolumn{8}{|c|}{ Animal Groups } & \multirow{2}{*}{$\begin{array}{c}\text { ANOVA } \\
\mathrm{P}\end{array}$} \\
\hline & & & Con. & B.S. & B.H. & $\begin{array}{l}\text { B.S.+ } \\
\text { B.H. }\end{array}$ & $\begin{array}{r}\mathrm{NaNO}_{2} \\
+ \text { S.S.Y. }\end{array}$ & $\begin{array}{c}\mathrm{NaNO}_{2} \\
+ \text { S.S.Y. } \\
+ \text { B.S. }\end{array}$ & $\begin{array}{l}\mathrm{NaNO}_{2} \\
+ \text { S.S.Y. } \\
+ \text { B.H. }\end{array}$ & $\begin{array}{l}\mathrm{NaNO}_{2} \\
+ \text { S.S.Y. } \\
+ \text { B.S. }+ \\
\text { B.H. }\end{array}$ & \\
\hline \multirow{4}{*}{ 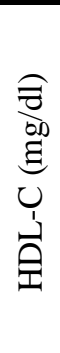 } & \multicolumn{2}{|c|}{ Mean } & 43.8 & 43.8 & 43.8 & 44.1 & 30.1 & 47.5 & 47.1 & 47.3 & \multirow[t]{4}{*}{$\mathrm{P}<0.05$} \\
\hline & \multicolumn{2}{|c|}{$\pm \mathrm{SE}$} & 0.55 & 0.42 & 0.55 & 0.40 & $0.83^{\mathrm{a}}$ & $0.32^{\mathrm{a} \& \mathrm{~b}}$ & $0.31^{\mathrm{a} \& \mathrm{~b}}$ & $0.36^{a \& b}$ & \\
\hline & \multirow{2}{*}{$\begin{array}{c}\% \text { of } \\
\text { change }\end{array}$} & $*$ & & 0 & 0 & $\begin{array}{c}+ \\
0.45\end{array}$ & -31.2 & +8.4 & +7.5 & +7.9 & \\
\hline & & $\begin{array}{l}* \\
*\end{array}$ & & & & & & +57.8 & +56.4 & +57.1 & \\
\hline \multirow{4}{*}{ 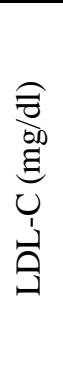 } & \multicolumn{2}{|c|}{ Mean } & 18.9 & 18 & 18.1 & 17.8 & 45.9 & 9.4 & 10.2 & 10 & $\mathrm{P}<0.05$ \\
\hline & \multicolumn{2}{|c|}{$\pm \mathrm{SE}$} & 0.65 & 0.68 & 0.99 & 0.39 & $0.73^{\mathrm{a}}$ & $0.60^{\mathrm{a} \& \mathrm{~b}}$ & $0.89^{\mathrm{a} \& \mathrm{~b}}$ & $0.44^{\mathrm{a} \& \mathrm{~b}}$ & \multirow{3}{*}{ S } \\
\hline & \multirow{2}{*}{$\begin{array}{c}\% \text { of } \\
\text { change }\end{array}$} & $*$ & & -4.7 & -4.7 & -5.8 & +142.8 & -50.2 & -46 & -47 & \\
\hline & & $\begin{array}{l}* \\
*\end{array}$ & & & & & & -79.5 & -77.7 & -78.1 & \\
\hline \multirow{4}{*}{ 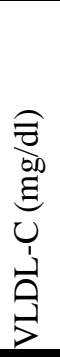 } & \multicolumn{2}{|c|}{ Mean } & 15.3 & 15.1 & 14.8 & 14.7 & 23.1 & 15.9 & 14.6 & 14.6 & $\mathrm{P}<0.05$ \\
\hline & \multicolumn{2}{|c|}{$\pm \mathrm{SE}$} & 0.34 & 0.34 & 0.31 & 0.33 & $0.23^{\mathrm{a}}$ & $0.39^{\mathrm{b}}$ & $0.41^{\mathrm{b}}$ & $0.39^{\mathrm{b}}$ & \multirow{3}{*}{ S } \\
\hline & \multirow{2}{*}{$\begin{array}{c}\% \text { of } \\
\text { change }\end{array}$} & * & & -1.9 & -3.2 & -3.9 & +50.9 & +3.9 & -4.5 & -4.5 & \\
\hline & & $\begin{array}{l}* \\
*\end{array}$ & & & & & & -31.1 & -36.7 & -36.7 & \\
\hline \multirow{4}{*}{ 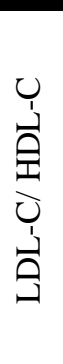 } & \multicolumn{2}{|c|}{ Mean } & 0.43 & 0.41 & 0.41 & 0.40 & 1.5 & 0.20 & 0.22 & 0.21 & \multirow[t]{4}{*}{$P<0.00$} \\
\hline & \multicolumn{2}{|c|}{$\pm \mathrm{SE}$} & 0.02 & 0.02 & 0.02 & 0.001 & $0.06^{\mathrm{a}}$ & $0.01^{\mathrm{a} \& \mathrm{~b}}$ & $0.02^{\mathrm{a} \& \mathrm{~b}}$ & $0.01^{a \& b}$ & \\
\hline & \multirow{2}{*}{$\begin{array}{c}\% \text { of } \\
\text { change }\end{array}$} & * & & -4.6 & -4.6 & -6.9 & +248.8 & -53.4 & -48.8 & -51.1 & \\
\hline & & $\begin{array}{l}* \\
*\end{array}$ & & & & & & -86.6 & -85.3 & -86 & \\
\hline \multirow{4}{*}{ 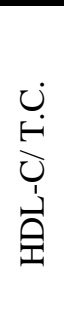 } & \multicolumn{2}{|c|}{ Mean } & 0.56 & 0.57 & 0.57 & 0.58 & 0.31 & 0.65 & 0.66 & 0.66 & $\mathrm{P}<0.05$ \\
\hline & \multicolumn{2}{|c|}{$\pm \mathrm{SE}$} & $\begin{array}{c}0.01 \\
0\end{array}$ & 0.005 & 0.008 & 0.003 & $0.006^{\mathrm{a}}$ & $0.008^{a \& b}$ & $0.009^{a \& b}$ & $0.008^{a \& b}$ & \multirow[t]{3}{*}{ S } \\
\hline & \multirow{2}{*}{$\begin{array}{c}\% \text { of } \\
\text { change }\end{array}$} & $*$ & & +1.7 & +1.7 & +3.5 & -44.6 & +16.1 & +17.8 & +17.8 & \\
\hline & & * & & & & & & +109.6 & +112.9 & +112.9 & \\
\hline
\end{tabular}

Results are presented as means \pm SE and $\%$ of change ( $\mathrm{n}=6$ for each group).

$\%$ of change compared to control group $(*)$ or compared to $\mathrm{NaNO}_{2}+$ S.S.Y group (**).

Significant change at $\mathrm{p} \leq 0.05$ compared to control group $\left({ }^{\mathrm{a}}\right)$ or compared to $\mathrm{NaNO}_{2}+$ S.S.Y. group $\left({ }^{b}\right)$.

B.S. : Black seeds.

B.H. : Bees honey.

S.S.Y. : Sunset yellow. 
The role of black seed and/ or bees honey

Table 3: Heart lipid profiles in control and different treated rat groups.

\begin{tabular}{|c|c|c|c|c|c|c|c|c|c|c|c|}
\hline & & & \multicolumn{8}{|c|}{ Animal Groups } & \multirow{2}{*}{ 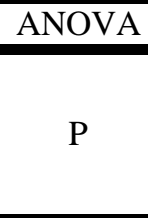 } \\
\hline & & & Con & B.S. & B.H. & $\begin{array}{l}\text { B.S.+ } \\
\text { B.H. }\end{array}$ & $\begin{array}{c}\mathrm{NaNO}_{2} \\
+ \\
\text { S.S.Y. }\end{array}$ & $\begin{array}{c}\mathrm{NaNO}_{2} \\
+ \text { S.S.Y. } \\
\text { + B.S. }\end{array}$ & $\begin{array}{l}\mathrm{NaNO}_{2} \\
+ \text { S.S.Y. } \\
+ \text { + B.H. }\end{array}$ & $\begin{array}{r}\mathrm{NaNO}_{2} \\
+ \text { S.S.Y. } \\
+ \text { B.S. } \\
\text { B.H. }\end{array}$ & \\
\hline \multirow{4}{*}{ 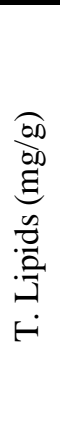 } & \multicolumn{2}{|c|}{ Mean } & 28.2 & 27.1 & 26.9 & 26.4 & 62.9 & 33.7 & 33.6 & 32.4 & \\
\hline & \multicolumn{2}{|c|}{$\pm \mathrm{SE}$} & 0.17 & $0.23^{\mathrm{a}}$ & $0.24^{a}$ & $0.22^{a}$ & $0.11^{\mathrm{a}}$ & $0.08^{a \& b}$ & $0.08^{a \& b}$ & $0.08^{a \& b}$ & \\
\hline & \multirow{2}{*}{$\begin{array}{c}\% \text { of } \\
\text { change }\end{array}$} & * & & -3.9 & -4.6 & -6.3 & +123 & +19.5 & +19.1 & +14.8 & \\
\hline & & * & & & & & & -46.4 & -46.5 & -48.4 & \\
\hline \multirow{4}{*}{ 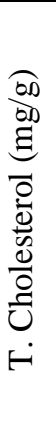 } & \multicolumn{2}{|c|}{ Mean } & 10.1 & 9.8 & 9.7 & 9.4 & 25.7 & 14.4 & 14.4 & 13.9 & $\mathrm{P}<0.05$ \\
\hline & \multicolumn{2}{|c|}{$\pm \mathrm{SE}$} & 0.08 & 0.11 & 0.13 & $0.17^{\mathrm{a}}$ & $0.11^{\mathrm{a}}$ & $0.15^{\mathrm{a} \& \mathrm{~b}}$ & $0.15^{\mathrm{a} \& \mathrm{~b}}$ & $0.09^{\mathrm{a} \& \mathrm{~b}}$ & \\
\hline & \multirow{2}{*}{$\begin{array}{l}\% \text { of } \\
\text { change }\end{array}$} & $*$ & & -2.9 & -3.9 & -6.9 & +154.4 & +42.5 & +42.5 & +37.6 & \\
\hline & & $* *$ & & & & & & -43.9 & -43.9 & -45.9 & \\
\hline \multirow{4}{*}{ 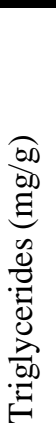 } & \multicolumn{2}{|c|}{ Mean } & 12.2 & 11.5 & 11.4 & 11.3 & 27.4 & 12.3 & 12.3 & 12.2 & $\mathrm{P}<0.05$ \\
\hline & \multicolumn{2}{|c|}{$\pm \mathrm{SE}$} & 0.08 & $0.09^{\mathrm{a}}$ & $0.10^{\mathrm{a}}$ & $0.09^{\mathrm{a}}$ & $0.19^{\mathrm{a}}$ & $0.26^{\mathrm{b}}$ & $0.06^{\mathrm{b}}$ & $0.47^{\mathrm{b}}$ & \\
\hline & \multirow{2}{*}{$\begin{array}{c}\% \text { of } \\
\text { change }\end{array}$} & $*$ & & -5.7 & -6.5 & -7.3 & +124.5 & +0.81 & +0.81 & 0 & \\
\hline & & $* *$ & & & & & & -55.1 & -55.1 & -55.4 & \\
\hline \multirow{4}{*}{ 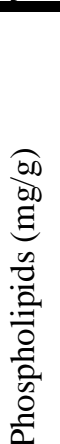 } & \multicolumn{2}{|c|}{ Mean } & 5.8 & 5.7 & 5.7 & 5.6 & 9.6 & 6.9 & 6.8 & 6.2 & $\mathrm{P}<0.05$ \\
\hline & \multicolumn{2}{|c|}{$\pm \mathrm{SE}$} & 0.13 & 0.13 & 0.14 & 0.13 & $0.17^{\mathrm{a}}$ & $0.12^{a \& b}$ & $0.14^{\mathrm{a} \& \mathrm{~b}}$ & $0.07^{\mathrm{b}}$ & \\
\hline & \multirow{2}{*}{$\begin{array}{c}\% \text { of } \\
\text { change }\end{array}$} & $*$ & & -1.7 & -1.7 & -3.4 & +65.5 & +18.9 & +17.2 & +6.8 & \\
\hline & & $* *$ & & & & & & -28.1 & -29.1 & -35.4 & \\
\hline
\end{tabular}

Results are presented as means $\pm \mathrm{SE}$ and $\%$ of change ( $\mathrm{n}=6$ for each group).

$\%$ of change compared to control group (*) or compared to $\mathrm{NaNO}_{2}+$ S.S.Y group (**).

Significant change at $\mathrm{p} \leq 0.05$ compared to control group $\left({ }^{\mathrm{a}}\right)$ or compared to $\mathrm{NaNO}_{2}+$ S.S.Y. group $\left({ }^{b}\right)$.
B.S. : Black seeds.
B.H. : Bees honey.
S.S.Y. : Sunset yellow. 
Wafaa M. El-Kholy et al

Table 4: Serum and heart enzymes activity in control and different treated rat groups.

\begin{tabular}{|c|c|c|c|c|c|c|c|c|c|c|c|}
\hline & & & \multicolumn{8}{|c|}{ Animal Groups } & \multirow{2}{*}{$\begin{array}{c}\text { ANOVA } \\
\mathrm{P}\end{array}$} \\
\hline & & & Con. & B.S. & B.H. & $\begin{array}{l}\text { B.S.+ } \\
\text { B.H. }\end{array}$ & $\begin{array}{l}\mathrm{NaNO}_{2} \\
+ \text { S.S.Y. }\end{array}$ & $\begin{array}{c}\mathrm{NaNO}_{2} \\
+ \text { S.S.Y. } \\
+ \text { B.S. }\end{array}$ & $\begin{array}{c}\mathrm{NaNO}_{2} \\
+ \text { S.S.Y. } \\
+ \text { B.H. }\end{array}$ & $\begin{array}{l}\mathrm{NaNO}_{2} \\
+ \text { S.S.Y. } \\
+ \text { B.S. }+ \\
\text { B.H. }\end{array}$ & \\
\hline \multirow{4}{*}{ 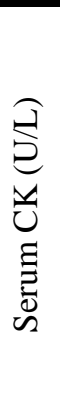 } & \multicolumn{2}{|c|}{ Mean } & 207.7 & 204.6 & 204.3 & 203.1 & 343.3 & 273.7 & 273.3 & 270.5 & \\
\hline & \multicolumn{2}{|c|}{$\pm \mathrm{SE}$} & 2.7 & 3 & 1.9 & 1.6 & $1.9^{\mathrm{a}}$ & $2.6^{\mathrm{a} \& \mathrm{~b}}$ & $2.2^{\mathrm{a} \& \mathrm{~b}}$ & $1.3^{\mathrm{a} \& \mathrm{~b}}$ & \\
\hline & \multirow{2}{*}{$\begin{array}{c}\% \text { of } \\
\text { change }\end{array}$} & $*$ & & -1.4 & -1.6 & -2.2 & +65.2 & +31.7 & +31.5 & +30.2 & \\
\hline & & $\begin{array}{l}* \\
*\end{array}$ & & & & & & -20.2 & -20.3 & -21.2 & \\
\hline \multirow{4}{*}{ 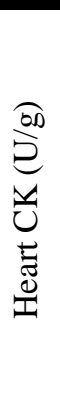 } & \multicolumn{2}{|c|}{ Mean } & 338 & 337.2 & 335.8 & 335.6 & 502.7 & 435.4 & 420.7 & 368.4 & \\
\hline & \multicolumn{2}{|c|}{$\pm \mathrm{SE}$} & 1.2 & 1.4 & 1.4 & 1.2 & $4.2^{\mathrm{a}}$ & $1.6^{\mathrm{a} \& \mathrm{~b}}$ & $1.4^{\mathrm{a} \& \mathrm{~b}}$ & $1.4^{\mathrm{a} \& \mathrm{~b}}$ & \\
\hline & \multirow{2}{*}{$\begin{array}{c}\% \text { of } \\
\text { change }\end{array}$} & $*$ & & -0.23 & -0.65 & -0.71 & +48.7 & +28.8 & +24.4 & +8.9 & \\
\hline & & $\begin{array}{l}* \\
*\end{array}$ & & & & & & -13.3 & -16.3 & -26.7 & \\
\hline \multirow{4}{*}{ 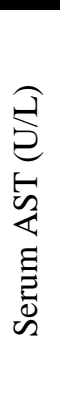 } & \multicolumn{2}{|c|}{ Mean } & 35.9 & 34.1 & 34.1 & 34 & 64.9 & 44.2 & 43.2 & 39.8 & $\mathrm{P}<0.05$ \\
\hline & \multicolumn{2}{|c|}{$\pm \mathrm{SE}$} & 0.93 & 0.90 & 0.98 & 0.71 & $1.1^{\mathrm{a}}$ & $0.32^{\mathrm{a} \& \mathrm{~b}}$ & $0.54^{\mathrm{a} \& \mathrm{~b}}$ & $0.35^{\mathrm{a} \& \mathrm{~b}}$ & \\
\hline & \multirow{2}{*}{$\begin{array}{c}\% \text { of } \\
\text { change }\end{array}$} & $*$ & & -5 & -5 & -5.2 & +80.7 & +23.1 & +20.3 & +10.8 & \\
\hline & & $\begin{array}{l}* \\
* \\
*\end{array}$ & & & & & & -31.8 & -33.4 & -38.6 & \\
\hline \multirow{4}{*}{ 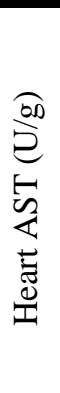 } & \multicolumn{2}{|c|}{ Mean } & 25.1 & 24.6 & 24 & 23.9 & 78 & 50.5 & 50.2 & 47.1 & $\mathrm{P}<0.05$ \\
\hline & \multicolumn{2}{|c|}{$\pm \mathrm{SE}$} & 1 & 0.60 & 0.61 & 0.55 & $0.39^{\mathrm{a}}$ & $1.1^{\mathrm{a} \& \mathrm{~b}}$ & $0.82^{a \& b}$ & $0.66^{a \& b}$ & \\
\hline & \multirow{2}{*}{$\begin{array}{c}\% \text { of } \\
\text { change }\end{array}$} & $*$ & & -1.9 & -4.3 & -4.7 & +210.7 & +101.1 & +100 & +87.6 & \\
\hline & & $\begin{array}{l}* \\
*\end{array}$ & & & & & & -35.2 & -35.6 & -39.6 & \\
\hline
\end{tabular}

Results are presented as means $\pm \mathrm{SE}$ and $\%$ of change ( $\mathrm{n}=6$ for each group).

$\%$ of change compared to control group (*) or compared to $\mathrm{NaNO}_{2}+$ S.S.Y group (**).

Significant change at $\mathrm{p} \leq 0.05$ compared to control group $\left({ }^{\mathrm{a}}\right)$ or compared to $\mathrm{NaNO}_{2}+$ S.S.Y. group $\left({ }^{\mathrm{b}}\right)$.

B.S. : Black seeds. $\quad$ B.H. : Bees honey. $\quad$ S.S.Y. : Sunset yellow. 
The role of black seed and/ or bees honey

Table 5: Heart oxidative stress and some antioxidants in control and different treated rat groups.

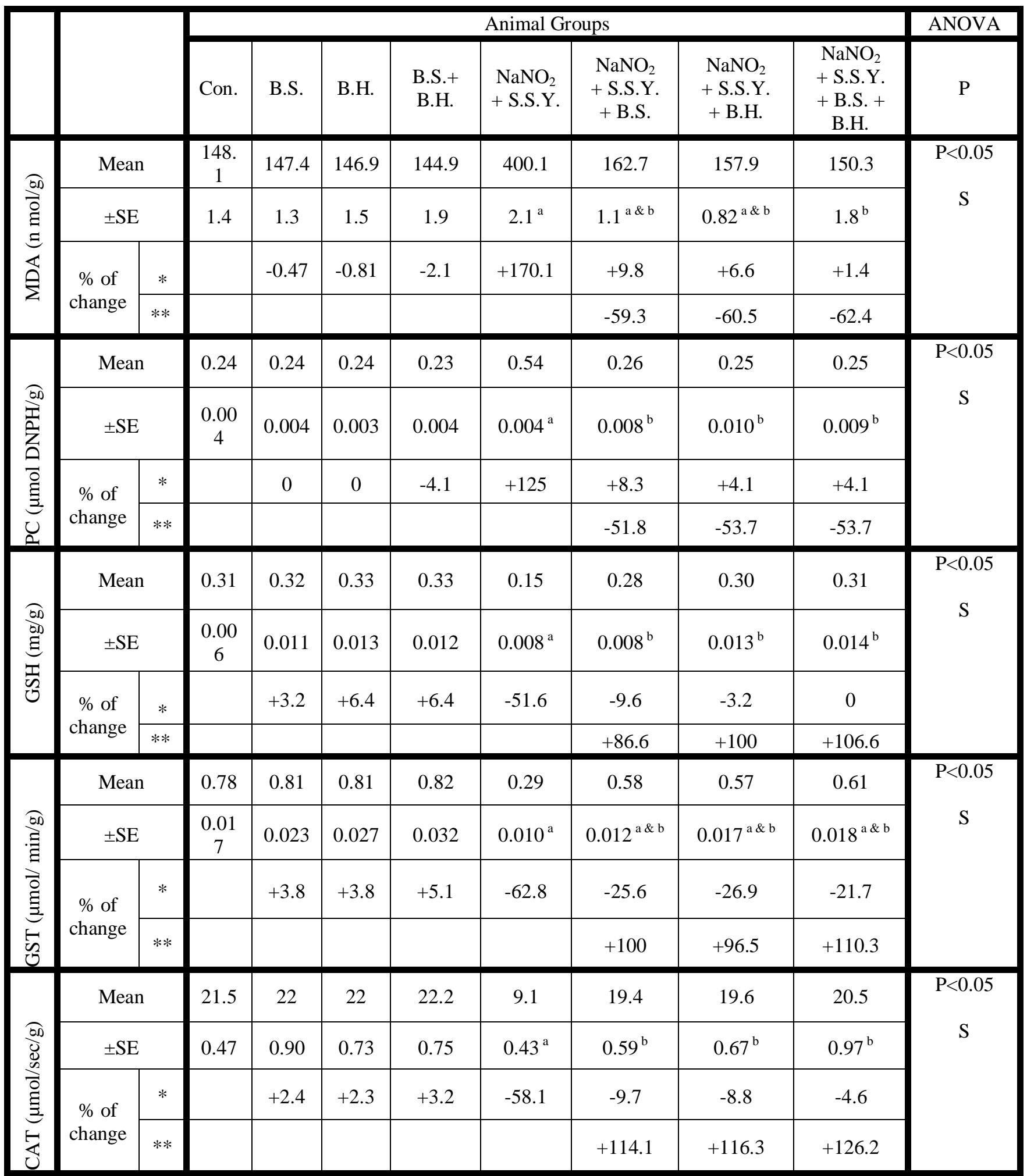

Results are presented as means \pm SE and $\%$ of change ( $\mathrm{n}=6$ for each group).

$\%$ of change compared to control group (*) or compared to $\mathrm{NaNO}_{2}+$ S.S.Y group (**).

Significant change at $\mathrm{p} \leq 0.05$ compared to control group $\left({ }^{\mathrm{a}}\right)$ or compared to $\mathrm{NaNO}_{2}+$ S.S.Y. group $\left({ }^{\mathrm{b}}\right)$.

B.S. : Black seeds. $\quad$ B.H. : Bees honey. S.S.Y. : Sunset yellow. 


\section{Discussion}

Nowadays, food additives are considered to be one of the difficult problems in food industry (Ismail et $a l ., 2003)$. On the other hand, there is a good evidence that the dietary factors play a key role in alleviating the hazard effects of these toxic compounds and maintaining the human health (Fong, 2002).

The present results indicated significant changes in serum and heart lipids and lipoprotein fractions in rats fed on $\mathrm{NaNO}_{2}$ plus sunset yellow. These results are similar to the findings of Mathur et al. (2005) who showed a significant disturbance in various lipid fractions in sunset yellow fed rats. The adverse effects of nitrated diet on lipid metabolism may occure in relation to peroxidation (Heiabshy and Abdel El Moneim, 1999). Where nitrites has been indicated to act as cell membrane oxidants (Beaupre and schiffman, 1994). This suggestion may support the finding of Bruning-Fann and Kaneene (1993) that nitrite ingestion in monogastric animals has been linked to interference with the metabolism of the antioxidants. Hence, the increased level of serum cholesterol, phospholipids and triglycerides noted here in rats exposed to the $\mathrm{NaNO}_{2}$ plus sunset yellow could be attributed to the peroxidation of cell membrane lipids as well as the decrease in the antioxidants (Standberg, 1997).

Indeed, the overall effects of $\mathrm{NaNO}_{2}$ plus sunset yellow feeding diet were the undesirable rise in serum LDL/HDL-C ratio and a decline in the HDL-C/TC ratio, where these ratios are strong marker for coronary heart diseases, as reduction of LDL/HDL ratio is of primary importance in reducing risk of cardiovascular disease (Walldius et al., 2001).

However, the administration of black seed caused marked improvement in lipid and lipoprotein profiles. Similar results were obtained by Le et al. (2004). Thus, the antihyperlipidemic effect of black seed might prevent the deposition of lipids in tissues and arteries, preventing tendency to obesity and atherogenesis by decreasing serum LDL-c and enhancing HDL-C (Le et al., 2004). In addition, the linoleic acid ethyl and methyl esters and linolenic acid ethyl ester found in the volatile oil together with the polyunsaturated fatty acids in the fixed oil fraction of the black seeds may lead to the decrease in serum total and LDL cholesterol (Wollett et al. 1992).

Also, a marked improvement in lipid fractions was observed after bees honey administration. The decrease of lipid fractions due to bees honey treatment has been reported in rats (Busserolles et al., 2002) and sheep (Al-Waili, 2003). It is not surprising result, since, honey contains 4 to 5\% fructoligosaccharides (FOS) which serve as prebiotic agents (Chow, 2002) and contribute to lipid lowering effect of honey (Delzenne and Kok, 1999). This effect appears to be mainly due to the reduced secretion of VLDL-C particles from the liver and associated with the reduced gene expressions and activities of lipogenic enzymes. Dietary fermentable carbohydrates, also may delay carbohydrates absorption, leading to decreased lipogenic activity in the liver (Shamala et al., 2000).

Concerning the heart status, the present results indicated significant increases in serum and heart CK and AST enzymes activity in rats treated by $\mathrm{NaNO}_{2}$ plus sunset yellow. This increase is in accordance with Ahmed and Mannaa (2000). The elevation of CK enzyme activity could be attributed to a generalized increase in membrane activity and is particularly useful in the diagnosis of muscular disorder, especially progressive muscular dystrophy (Helal and Abdel Rahman, 2005). However, Rybczynska et al. (1996) found that lipid peroxidation of cell membrane is associated with inactivation of membrane bound enzymes. Based on these molecular events, it is possible to explain systematic elevated activity of serum CK and AST in $\mathrm{NaNO} 2$ plus sunset yellow treated rats. 
On the other side, the administration of black seed showed significant reduction in CK and AST activities. This result is in agreement with Bawadi and Losso (2005) who indicated that the use of black seeds lead to improved heart functions and fall of elevated heart enzymes (CK and AST) activity. These observations may be due to the natural phenolic compounds of black seeds oil which may have a positive effect in the prevention of heart diseases via their antioxidant effects (Tuck and Hay ball, 2002).

Additionally, bees honey administration, herein, reduced $\mathrm{CK}$ and AST enzymes activity. This view was supported by Wiliams (2004), who recorded decreased CK and AST enzymes activity. This finding may be due to that honey contains flavonoids which were associated with decreased LDL-C level and consequently decreased coronary heart disease risk (Langseth, 2000).

Moreover, the current result showed increased MDA in heart of rats treated by $\mathrm{NaNO}_{2}$ plus sunset yellow. Such result is in accordance with Popova and Popova (2005) who showed that nitrites are strong stimulators of lipid peroxidation and influence the permeability of lysosome membranes. The elevated amounts of MDA may be due to generation of reactive oxygen species (ROS) and free radical originating from the metabolism of nitrosamine and also, attributed to the depletion of liver GSH resulting in tissue degeneration and accumulation of lipid peroxidation products in target organs (Bansal et al., 2005).

On the other hand, the administration of black seeds reduced MDA level. This result is in harmony with Knater et al. (2006). This ameliorative effect may be due to the combined antioxidant properties of thymoquinone and its metabolite dihydrothymoquinone (DHTQ) which present in the seeds and have the potential to inhibit free radical induced lipid peroxidation (Nagi et al., 1999).

Furthermore, the obtained decreased MDA level due to bees honey administration is in accordance with Busserolles et al. (2002) who found decreased susceptibility of heart lipids to peroxidation in rats fed honey based diet. This effect may be due to that honey contains flavonoid compounds (Merken and Beecher 2000) known for their hydrogen donating antioxidant activities. In addition, honey contains phenolic compounds known for their capacity to reduce and chelate ferric ion which catalyze lipid peroxidation (Gazzani et al., 1998).

The present results indicated significant increase in heart carbonyl protein in rats treated by $\mathrm{NaNO}_{2}$ and sunset yellow. These results are similar to the findings of Adams et al. (2001). In fact, the obtained elevation in protein oxidation level could be attributed mainly to nitrite- induced generation of reactive oxygen species which may damage all types of biological molecules such as proteins, lipids and convert some amino acid residues of protein to carbonyl derivative (Shacter, 2000).

However, the administration of black seed recorded marked reduction in protein carbonyl concentration. These results are in harmony with the previous studies of Suboh et al. (2004), who showed that black seed has anti-protein- oxidant activity. These findings may be due to that the crude black seed oil and its fractions (Neutral lipids, glycolipids and phospholipids) have potent radical scavenging activity that is correlated well with their total content of polyunsaturated fatty acids, unsaponifiables, and phospholipids as well as the with initial peroxide values of crude oils (Ramadan et al., 2003).

Alternatively, honey has been proven to be effective against deteriorative oxidation reaction, induced herein by $\mathrm{NaNO}_{2}$ and sunset yellow, mainly due to its antioxidant capacity (Al-Mammary et al., 2002) related to its antioxidant compounds as flavonoids and phenolic acids.

The current study indicated significant decrease in GSH content as well as GST and catalase enzymesactivity in rats administrated $\mathrm{NaNO}_{2}$ plus sunset yellow. Such results are in agreement with Popova and Popov (2005). This result may be due to the consumption of antioxidants and the increased production of ROS due to the toxic action of nitrosamine (Chiarello et al., 1998).

However, the administration of black seed showed marked improvement in the 
GSH content and GST and catalase activities. These results are in agreement with El-Saleh et al. (2004). This improvement may be due to the antioxidant activity of black seed which contributed to the presence of unsaturated fatty acids (Houghton et al., 1995) and its high phenolic contents (nigellon and nigonol) (Besbes et al., 2005) through a mechanism including scavenging of the reactive molecular species (Wood et al., 1982).

Moreover, the present results exhibited a clear protective action of bees honey against the deleterious effects on the antioxidant status. This observation is in harmony with Nasuti et al. (2006). This improvement may be correlated to the phenolic compounds constituents of bees honey which having reducing power and antioxidant activity through a number of different mechanisms, such as free radical scavenging, hydrogen- donation, single oxygen quenching, metal ion chelation and acting as a substrate for radicals (Buratti et al., 2007).

In conclusion, the results obtained in the present study revealed a highly adverse action of the co-administration of nitrite and sunset yellow. However, black seeds or bees honey have an effective role in reducing the harmful effects of nitrite and sunset yellow through their natural antioxidants. Therefore, the present study recommended that sustained levels of black seeds and bees honey must be added to overcome the deleterious action of such additives.

\section{References}

1. Adams S, Green P, Claxton R, Simcox S, Williams $M \quad V$, Walsh $K$ and Leeuwenburggh $\mathbf{C}$ (2001): Reactive carbonyl formation by oxidative and non-oxidative pathways. Front. Biosci., 6(A): 17-24.

2. Ahmed $H \quad H$ and Manna $F$ (2000): Protective effect of vitamins $\mathrm{C}$ and $\mathrm{E}$ against the toxic action of drinking sodium nitrate contaminated water in adult male rats. J. Egypt. Ger. Soc. Zool., Comparative Physiology, 32(A): 165-185.

3. Aljadi A M and Kamaruddin M Y (2004): Evaluation of the phenolic content and antioxidant capacities of two Malaysian floral honeys. Food Chem., 85: 513 - 518.
4. Al-Mamary M, Al-Meerib A and AlHaborib M (2002): Antioxidant activities and total phenolics of different types of honey. Nutr. Res., 22: 1041 - 1047.

5. Al-Waili N S (2003): Intravenous and intrapulmonary administration of honey solution to healthy sheep effects on blood sugar, renal and liver function tests, bone marrow function, lipid profile, and carbon tetrachloride - induced liver injury. J. of Med. Food, 6(3): 231-274.

6. Babayan V K, Koottungal $O$ and Halaby G A (1978): proximate analysis, fatty acid and amino acid composition of Nigella sativa L. seeds. J. Food Sci., 143 (4): 1314 $-1315$.

7. Baginiski $\mathbf{E} \mathbf{B}$, Ipstein $\mathbf{E}$ and Zak $\mathbf{B}$ (1972): Determination of phospholipids in plasma. Ann. Clin. Lab. Sci. 2: 255 - 260.

8. Bansal A K, Bansal $\mathbf{M}$, Soni $\mathbf{G}$ and Bhatnagar D (2005): Protective role of vitamin $\mathrm{E}$ pretreatment of $\mathrm{N}$-nitrosodiethyl amine induced oxidative stress in rat liver. Chemico. Biol. Int., 156: 101-111.

9. Bawadi H A and Losso J N (2005): Hypoxia inducible factor pathways as targets for function foods. J. Agric. and Food Chem., 53(10): 3751 - 3768.

10. Beaupre S R and Schiffman F J (1994): Rush hemolysis. A bile cell hemolytic anemia associated with volatile liquid nitrite use. Arch. Farm. Med., 3: 545-548.

11. Besbes S, Blecker C, Deroanne C, Lognay G, Drira N E and Attia H (2005): Heating effects on some quality characteristics of date seed oil. Food Chem., 91: 469 - 476.

12. Bock $\mathbf{P} \mathbf{P}$, Karmer $\mathbf{R}$ and Paverka $\mathbf{M}$ (1980): A simple assay for catalase determination. Cell Biol. Monogr., 7: $44-74$.

13. Bruning-Fann $\mathbf{C} \mathbf{S}$ and Kaneene $\mathbf{J} \mathbf{B}$ (1993): The effects of nitrate, nitrite and Nnitroso compounds on animal health. Vet. Hum. Toxicol., 35: $237-253$.

14. Buratti S, Benedtti S and Cosio M S (2007): Evaluation of the antioxidant power of honey, propolis and royal jally by amperometric flow injection analysis. Talanta, 71: 1387 - 1392.

15. Busserolles J, Gueux E, Mazur A and Rayssiguier Y (2002): Substituting honey for refined carbohydrates protects rats from hypertriglyceridemic and pro-oxidative effects of fructose. Soci. J. Nutr., 132: 3379-3382.

16. Caponio F, Alloggio $\mathbf{V}$ and Gomes $\mathbf{T}$ (1999): Phenolic compounds of virgin olive oil: influence of paste preparation techniques. Food Chem., 64: 203 - 209. 
17. Chiarello P G, Igiesias A C, Zucoloto S, Moreno F, Jordao A A and Vannucchi H (1998). Effect of a necrogenic dose of diethyl nitrosamine on vitamin $\mathrm{E}$ - deficient and vitamin E - supplemented rats. Food and Chem. Toxicol., Issue 11(36): 929 935.

18. Choi B C K (1985): N-Nitroso compounds and human cancer, a molecular epidemiologic approach. Am. J. Epidermol., 121: 734 - 737.

19. Chow J (2002): Probiotics and prebiotics: a brief overview. J. Ren. Nutr., 12:76 - 86.

20. Chung K T, Stevens S E and Cerniglia C E (1992): The reduction of azo dyes by the intestinal microflora. Crit. Rev. Microbiol., 18 (3): 175-190.

21. Combes $\mathbf{R} \mathbf{D}$ and Haveland-Smith $\mathbf{R} \mathbf{B}$ (1982): A review of genotoxicity of food, drug and cosmetic colours and other azotriphenyl methane and xanthene dyes. Mutat. Res., 98: 101-248.

22. Delzenne N M and Kok N N (1999): Biochemical basis of oligo fructose induced hypolipidemia in animal models. J. Nutr., 129: 14675 - 14705.

23. Desaint-Blanquat $G$, Fritsch $F$ and Cazotles C (1983): Effect of dietary nitrate and nitrite on experimentally induced inflammation in the rat. Intern. J. Tissue Reaction, 27: 173-180.

24. Egyptian Standard Organization (1989): Egyptian Standard Organization for Standardization and Quality Control. Nitrite and Nitrate in Meat Products. Egypt. PP: 227-229.

25. El-Kadi A and Kandil O C (1986): Effect of Nigella sativa (the black seed) on immunity. Proceeding of the $4^{\text {th }}$ international conference on Islamic Medicine, Kuwait. Bull. Islamic Med., 4: $344-348$.

26. El-Saleh S C, Al-Sagair $\mathrm{O} A$ and AlKhalaf M I (2004): Thymoquinone and Nigella sativa oil protection against methionine- induced hyperhomocysteinema in rats. Intern. J. cardiol., 93 (1):19- 23.

27. El-Zawahry B H (1997): Chemical composition of Nigella sativa L. seed. In: effect of Black seed on certain aspects of metabolism after feeding normal and hyperlipedemic diet in adult and old animals [MSc thesis in medical basic sciences]. Cairo, Egypt. Al-Azhar Univ., $16-28$.

28. Enomoto S, Asano R, Iwahori Y, Narui T, Okada Y, Singab A N and Okuyama T (2001): Hematological studies on black cumin oil from the seeds of Nigella sativa L. Biol. Pharm. Bull., 24(3): 307 - 310.
29. Ferreres C, Garciaviguera F, Tomaslorente F A (1993): Hesperetinc a marker of the floral origin of citrus honey. J. sci. Food Agric., 61: 121 - 123.

30. Fong H H (2002): Integration of herbal medicine into modern medicinal practices: issues and prospects. Integr Can. Ther., 1: $287-293$.

31. Friedewald W T, Levy $\mathbf{R} \quad \mathbf{I}$ and Fredrickson D S (1972): Estimation of the concentration of low density lipoprotein cholesterol in plasma, without use of the preparative ultracentrifuge. Clin. Chem., 18: 499 - 502.

32. Frings C S, Fendley T W, Dunn R T and Queen C A (1972): Improved determination of total serum lipids by the sulfo-phospho-vanillin reaction. Clin. Chem., 18: 673.

33. Furukawa F, Nishikawa A, Ishiwata H, Takahashi M, Hayashi $Y$ and Hiros $M$ (2000): Renal carcinogenicity of concurrently administrated fish meal and sodium nitrite in F344 rats. Jpn. J. Can. Res., 91: 139-147.

34. Gazzani G, Papetti A, Daglia M, Berte F And Gregotti C (1998): Protective activity of water soluble components of some common diet vegetables on rat liver microsomes and the effect of the thermal treatment. J. Agric. Food. Chem., 46: 4123 $-4127$.

35. Ghanem N F, Bakr S M E and Mira N M (2000): The preventive effect of the black seed powder on some pathological changes of the blood cells - induced in rats by a chemical carcinogen. J. Union. Arab. Biol., Cairo, 14(A): 177 - 195.

36. Habig W H, Pabst M J and Jakoby W B (1974): Glutathione $-\mathrm{s}$ - transferase the first enzyme step in mercapturic acid formation. J. Biol. Chem., 1(24a): 7150 7193.

37. Heibashy M A, and Abd El-Moneim A E (1999): Blood lipid profile and serum free thyroidal hormone concentrations in growing rats fed diets enriched with sodium nitrite for short and long terms. J. Egypt. Ger. Soc., 30 (A): 93-103.

38. Helal $E$ G $\mathbf{E}$ and Abdel-Rahman $M$ (2005): Interaction of sodium nitrite and sunset yellow and its effect on some biochemical parameters in albino rats. The Egypt. J. Hosp Med., 19: 156-167.

39. Houghton P J, Zarka R, Delas Heras B and Hoult J R (1995): Fixed oil of Nigella sativa and derived thymoqunione inhibit eicosanoid generation in leukocytes and membrane lipid peroxidation. Planta Med. Feb., 61(1): 33-36. 
40. Ismail A E M, Moustafa A M and Abd El-Rhaman G B (2003): Microscopic studies of the effect of some food additives on the kidney of albino rats. Egypt. J. Hosp. Med., 12: 12-27.

41. Jahries G, Hesse V I, Schone L H and Mehnert E (1986): Influence of nitrates and plant goitrgens on thyroid hormone, somated in status and growth of swine. J. Vet. Med., 41(15): 528-530.

42. Jennings A S, Schwartz S L, Batter N J, Gardner $D$ and Witorsch $T$ (1990): Effects of oral erythrosine $\left(2^{\prime}, 4^{\prime}, 5^{\prime}, 7^{\prime}-\right.$ tetraiodo-fluorescein) on the pituitary thyroid axis in rats. Toxicol. Appl. Pharmacol., 103: 549 -556.

43. Kanter M, Coskun O, Kalayci M, Buyukabs S and Cagavi F (2006): Neuroprotective effects of Nigella sativa on experimental spinal cord injury in rats. Hum. Exp. Toxicol., 25(3): 127 - 133.

44. Langseth L (2000): Antioxidants and the Prevention of Cancer. In: Oxidants, Antioxidants, and Disease Prevention. ILSI Europe Concise Monographs. ILSI Press. Belgium. PP. 7 - 13.

45. Le $\mathbf{P}$ M, Benhaddou A A, Settaf A, Cherrah Y and Haddad P S (2004): The petroleum ether extract of Nigella sativa exerts lipid powering action in the rats. J. Ethano. Pharm., 94(2-3): $251-259$.

46. Lindsay R C (1985): Food Additives In Fennema. Cited in: Food Additives Intolerance In Childhood. P. 179. Ed. David, T.J. Blackwell Scientific. London Boston.

47. Mathur N, Chaudhary V, Mehta $M$ and Gupta S (2005): Sunset yellow induced changes in the lipid profile in male albino rat. Biochem. Cell. Arch., 5(2): 197 - 200.

48. Merken $H$ M and Beecher G R (2000): Measurement of food flavonoids by high formance liquid chromatography: a review. J. Agri. Food. Chem., 48 (3): 577 - 599.

49. Nagi M N, Alam K, Badary O A, Alshabanab $O$ A, Al-Sawaf $\mathrm{H}$ A and AlBekairy A M (1999): Thymoquinone protects against carbon tetrachloride hepatotoxicity in mice via an antioxidant mechanism. Biochem. Mol. Biol. Int., 47(1): 153-159.

50. Nasuti C, Gabbianelli R, Falcioni G and Cantalamessa F (2006): Antioxidative and gastroprotective activities of anti-inflammatory formulations derived from chestnut honey in rats. Nutr. Res., 26: 130 - 137.

51. Ohkawa H, Wakatsuki A and Kaneda C (1982): Assay for lipid peroxides in animal tissues by thiobarbaturic acid reaction. Anal. Biochem., 95: 351 - 358.
52. Pollock I and Warner J O (1990): Effect of artificial food colors on childhood behavior. Arc. Dis. Child, 65: 74-77.

53. Popova $M P$ and Popov C S (2005): Effect of chemical agents on some enzyme activities and on the stability of membrane structures. Bulg. J. Vet. Med., 8(3): 163171.

54. Prins H K and Losse J A (1969): Glutathione. Chapter 4. Biochemical Methods in Red Cell Genetics. Edited Academic press. N.Y.D. London, PP. 126 - 129.

55. Ramadan M F, Kroh $\mathbf{L} \mathbf{W}$ and Morsel J T (2003): Radical scavenging activity of black cumin (Nigella sativa L.), coriander (Coriandrum sativum L.), and niger (Guizotia abyssinica cass.) crud seed oils and oil fractions. J. Agric. Food Chem., 51: $6961-6969$.

56. Reitman $\mathbf{S}$ and Frankel S (1957): Colorimetric estimation of serum transmainasis. Am. J. Clin. Path., 28: 56 - 63.

57. Rybczynska M, Hoffmann $\mathbf{S}$ and Goslar J (1996): Molecular changes in erythrocyte membranes induced by nitroimidazoles and radiation. Pol. J. Pharmacol., 48: 269 - 280.

58. Salomi M J, Nair S C and Panikkar K R (1991): Inhibitory effect of Nigella sativa and saffron (Crocus sativus) on chemical carocigenesis in mice. Nutr. Can., 16(1): 67 -72 .

59. Shacter E (2000): Protein oxidative damage. Methods Enzymol., 319: 428 -

60. Shamala T R, shrijyothi Y and Saibaba $P$ (2000): Stimulatory effect of honey on multiplication of lactic acid bacteria under in vitro and in vivo conditions. Lett. Appl. Microboil., 30: 453 - 455.

61. Smith C D, Carney J M, Starke-Reed P E, Oliver C N, Stadtman E R, Floyd R A and Markesbery W R (1991): Excess brain protein oxidation and enzyme dysfunction in normal aging and in Alzheimer disease. Proc. Natl. acad. Sci., 88: 105540 - 105543.

62. Snedecor G W and Cochran W G (1982): Statistical Methods $7^{\text {th }}$ ed. The Stae University Press Ametican, Iowa.

63. Standberg A S (1997): Nitrate and nitrite supply and metabolism in man. Nutr. Abs. Revs. Ser(A), 47: 1119.

64. Suboh S M, Bilto Y Y and Aburjai T A (2004): Protective effects of selected medicinal plants against protein degradation, lipid peroxidation and deformability loss of oxidatively stressed human erythrocytes. Phytother Res., 18: $280-284$.

65. Tuck K L and Hayball P J (2002): Major phenolic compounds in olive oil: 
metabolism and health effects. J. Nutr. Biochem., 13: 636 - 644 .

66. Walldius G, Junger I, Holme I, Aastveit A H, Kolar W and Steiner E (2001): High apolipoprotein B, low apolipoprotein A - I, and improvement in the prediction of fatal myocardial infarction (AMORIS study): A prospective study. Lancet, 358: 2026 2033.

67. Wiliams M N D (2004): Honey reduces heart disease risk. J. Med. Food, 1: 100 107.

68. Wollett L A, Spady D K and Dietschy J M (1992): Saturated and unsaturated fatty acids independently regulate low density lipoprotein receptor activity and production rate. J. Lipids Res., 33: $77-88$.

69. Wood A W, Huang M T, Chang R L, Newmark H L, Lehr R E, Yagi H, Sayer J M, Jerina D $M$ and Conney A $\mathbf{H}$
(1982): Inhibition of mutagenicity of bayregion diol- epioxides of polycyclic aromatic hydrocarbons by naturally occurring plant phenols, Exceptional activity of ellagic acid. Proc. Natl. Acad. Sci., 79: 5513 - 5517.

70. Yamada S, Itoh E, Murakami Y and Asano M (1999): Prevention of ethanol induced erythrocyte transformations by fructose and natural honey in low alcohol tolerance mice. Pathophysiol., 6: 163 - 170.

71. Young D S (1995): Effects of Drugs on Clinical Laboratory Tests, $4^{\text {th }}$ Ed AACC Press Washington D.C. PP. 4 - 57.

72. Young D S (1997): Effects of Drugs on Clinical laboratoy Tests, $3^{\text {rd }}$ Ed. AACC. PP. $579-581$

73. Zumla A and Lulat A (1989): Honey a remedy rediscovered. J. Roral Soc. Med., 82: $384-385$.

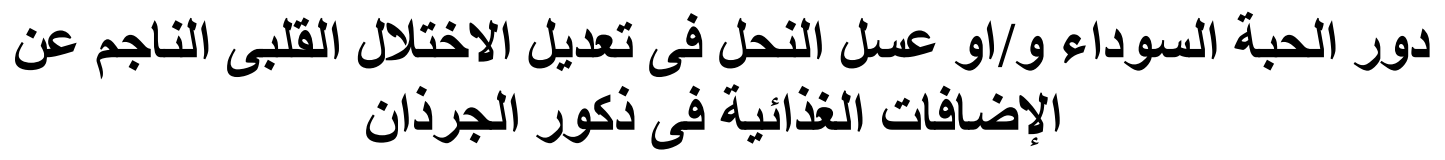




\section{وفاء محمد الخولى، هناء على حسن، سمر السبا نور}

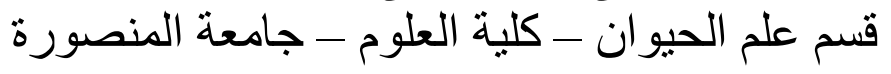

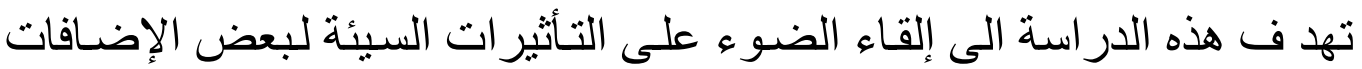

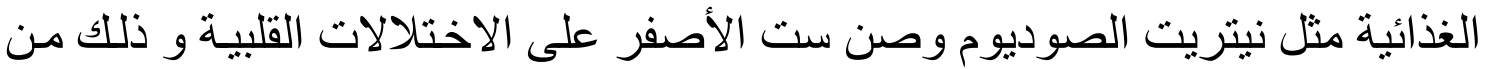

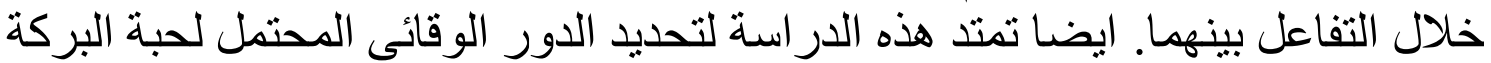

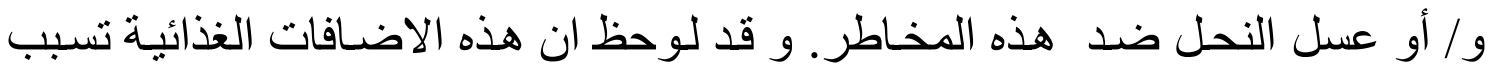

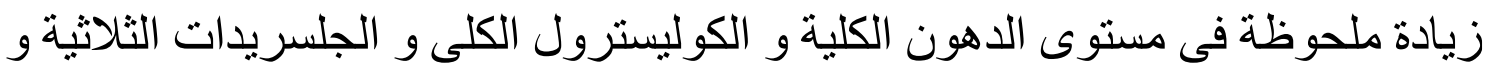

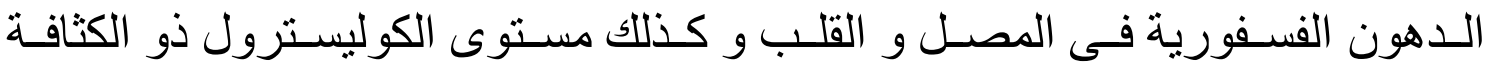

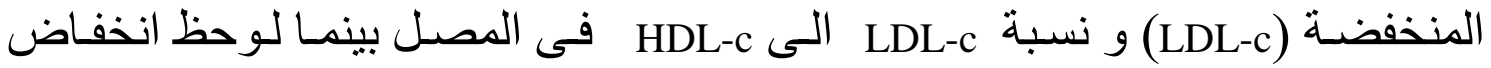

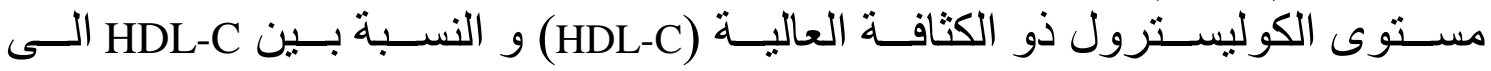

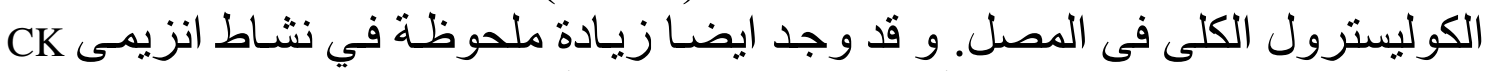

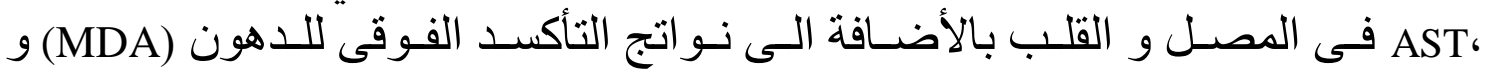

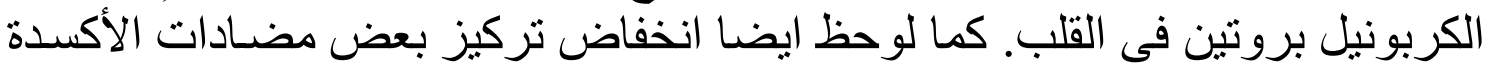

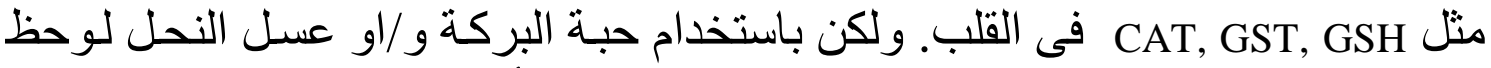

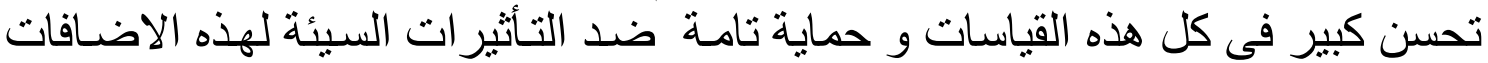

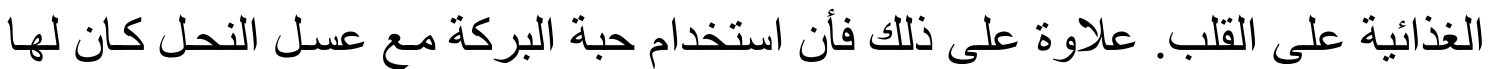
التأثنير الأمثل كما ان عسل النحل أظهر فعالية أكبر من حبة البركة. 